\title{
FUZZY INFERENCE SYSTEM SUGENO UNTUK EVALUASI KINERJA PELAYANAN PEGAWAI KANTOR CAMAT BATAM KOTA
}

\author{
Alfannisa Annurullah Fajrin") \\ ${ }^{1}$ Universitas Putera Batam \\ Email: asykharit1302@gmail.com
}

\begin{abstract}
Abstrak
Dalam proses kinerja lembaga, ujung tombak karyawan menjadi yang pertama dalam proses pengabdian masyarakat. Kinerja yang dimiliki oleh masing-masing karyawan akan menunjukkan kualitas karyawan dalam menjalankan tugasnya. Ini bertujuan untuk melihat sejauh mana kinerja yang dimiliki karyawan, perbaikan dan pemantauan kinerja bagi karyawan. Sehingga kepala karyawan bisa membuat keputusan memilih yang terbaik dari yang terbaik. Penilaian dilakukan terhadap orientasi pelayanan, integritas, disiplin dan kerja sama. Sejauh ini belum ada sistem yang bisa digunakan untuk mengetahui seberapa besar kinerja yang dimiliki oleh karyawan. Oleh karena itu, penelitian ini menggunakan sistem pengambilan keputusan dengan menggunakan logika fuzzy dengan metode orde nol Sugeno untuk menilai kinerja pegawai di Tembesi, Kecamatan Sagulung untuk pengolahan data menggunakan MATLAB. Langkah pertama penyelesaian evaluasi kinerja karyawan dengan menggunakan metode Sugeno dalam menentukan variabel input dan variabel output yang ditetapkan dengan baik, langkah kedua adalah mengkonversikan variabel input ke dalam rangkaian fuzzy dengan proses fuzzifikasi yang menghasilkan keputusan keluaran variabel kinerja pelayanan karyawan (Competent / Fair No Competent).
\end{abstract}

Kata Kunci: Kinerja Karyawan, fuzzylogic, Metode Sugeno

\begin{abstract}
In the process of institutional performance, the spearhead of employees becomes the first in the process of community service. Performance owned by each employee will show the quality of employees in performing their duties. It aims to see how far employees are performing, improving and monitoring performance for employees. So the chief employee can make the decision to choose the best of the best. Assessment is done on service orientation, integrity, discipline and cooperation. So far there is no system that can be used to find out how much performance owned by employees. Therefore, this research uses decision making system using fuzzy logic with Sugeno zero order method to assess the performance of employees in Tembesi, district Sagulung for data processing using MATLAB. The first step of completing employee performance evaluation using Sugeno method in determining input variables and well-defined output variables, the second step is to convert input variables into fuzzy circuit with fuzzification process the generates decision on output of employee service performance variable (Competent / Fair No Competent).
\end{abstract}

Keywords: Employee Performance, fuzzy logic, Sugeno Method .

\section{PENDAHULUAN}

Pelayanan publik (umum) dapat didefinisikan sebagai bentuk jasa pelayanan, jasa publik yang pada prinsipnya menjadi tanggung jawab dan dilaksanakan oleh Instansi Pemerintah. Kecamatan Batam Kota merupakan salah satu wilayah administrasi Kota Batam yang terdiri dari 12 (dua belas) Kecamatan yang ada di Kota Batam. Penilaian kinerja pegawai merupakan aspek penting untuk meningkatkan kualitas sumber daya yang sedang bersaing. Dengan adanya penilaian tersebut kita bisa mengetahui kondisi kerja dari pegawainya, efektif atau tidaknya. Kecamatan Batam Kota terbentuk berdasarkan Peraturan Daerah Kota Batam Nomor 2 tahun 2005, tentang Pemekaran, Perubahan, Pembentukan Kecamatan dan Kelurahan di Daerah Kota Batam. Dimana Pemekaran Kecamatan Sekupang merupakan salah satu dari bagian Kecamatan yang dimekarkan di Kota Batam ini dan Kecamatan Sekupang sebagai Kecamatan 
Induk yang dimekarkan menjadi 2 (dua) Kecamatan.

Dalam melakukan penilaian setiap instansi (lembaga) memiliki cara tersendiri. Salah satu metode untuk evaluasi kinerja pegawai camat yaitu menggunakan fuzzy inference system (FIS). Penelitian ini dibuat untuk mempermudah dalam mengevaluasi kinerja pelayanan pegawai, dan variabel yang ada berdasarkan data yang telah diperoleh dari kantor camat Batam Kota. Pelayanan di kantor lurah kibing kurang dari segi orientasi pelayanan yaitu mimik wajah dan suara yang tidak cocok dalam pelayanan. Waktu pengerjaan berkas-berkas masyarakat tidak tepat pada waktunya. Evaluasi pelayanan juga sangat terkait dengan kedisiplinan pegawai yang menyangkut mengenai waktu maupun jam kerja dari pegawai tersebut. Permasalahan yang sering terjadi adalah banyak pegawai yang semena-mena terhadap waktu bekerja. Sebagai contoh pada saat jam bekerja ada beberapa pegawai yang tidak ada ditempat dan mengakibatkan banyaknya masyarakat yang dirugikan dalam hal tersebut.

\section{TINJAUAN PUSTAKA Logika Fuzzy Sugeno}

Menurut Kusumadewi \& Purnomo (2010:1) Logika fuzzy merupakan salah satu komponen pembentuk soft computing. logika fuzzy pertama kali diperkenalkan oleh Prof. Lotfi A. Zadeh pada tahun 1965. Dasar logika fuzzy adalah teori himpunan fuzzy. Pada himpuanan fuzzy, peranan derajat keanggotaan sebagai penentu keberadaan elemen dalam suatu himpunan sangatlah penting. Nilai keanggotaan atau derajat keanggotaan atau membership function menjadi ciri utama dari penalaran dengan logika fuzzy tersebut.

Menurut Kusumadewi \& Purnomo (2010:1) Dalam banyak hal logika fuzzy digunakan sebagai suatu cara untuk memetakan permasalahan dari input menuju ke output yang diharapkan. Menurut Sri Kusumadewi (2010:46) penalaran dengan metode Sugeno hamper sama dengan penalaran Mamdani, hanya saja output (konsekuen) sistem tidak berupa himpunan fuzzy, melainkan berupa konstanta atau persamaan linear. Metode ini diperkenalkan oleh Takagi Sugeno Kang pada tahun 1985, sehingga metode ini sering juga dinamakan dengan metode TSK.

\section{Kinerja Pelayanan Pegawai}

Variabel menurut Sugiyono (2012:38) adalah segala sesuatu yang berbentuk apa saja yang ditetapkan oleh peneliti untuk dipelajari sehingga diperoleh informasi tentang hal tersebut, kemudian ditarik kesimpulannya.

Adapun variabel yang diambil dari kantor camat Batam Kota yaitu jenis penilaian seperti: (1) Orientasi Pelayanan, Merupakan sikap dan perilaku kerja pegawai dalam memberikan pelayanan terbaik kepada yang dilayani antara lain meliputi masyarakat, atasan, rekan sekerja, unit kerja terkait, dan atau instansi lain; (2) Integritas, kemampuan untuk bertindak sesuai dengan nilai, norma dan etika dalam organisasi; (3) kedisiplinan, kesanggupan pegawai untuk menaati kewajiban dan menghindari larangan yang ditentukan dalam peraturan perundang-undangan kedinasan yang apabila tidak ditaati atau dilanggar dijatuhi hukuman disiplin; (1) Kerjasama, kemauan dan kemampuan pegawai untuk bekerja sama dengan rekan sekerja, atasan, bawahan dalam unit kerjanya serta instansi lain dalam menyelesaikan suatu tugas dan tanggung jawab yang ditentukan, sehingga mencapai daya guna dan hasil guna yang baik.

\section{Matlab}

Menurut Agus (2009:39) Matlab adalah bahasa pemrograman tingkat tinggi dimana arti perintah dan fungsi-fungsi bisa dimengerti dengan mudah, meskipun bagi seorang pemula. Hal itu karena di dalam Matlab, masalah dan solusi bisa diekspresikan dalam notasi-notasi matematis yang biasa dipakai. Matlab singkatan dari matrix laboratory. Matlab juga telah menjadi alat bantu untuk keperluan analisis, pengembangan, riset dalam dunia industri. Spektrum penggunaan Matlab yang luas ini dikarenakan Matlab telah melengkapi diri dengan toolbox.

\section{HASIL DAN PEMBAHASAN}

Pembentukan Himpunan Fuzzy (Fuzzifikasi)

Untuk melakukan simulasi semua himpunan fuzzy maupun blok aturan harus dimasukkan kedalam sistem. Secara garis besar sistem ini akan memiliki 4 input (Orientasi Pelayanan, Integritas, Kedisiplinan dan Kerjasama) dan output (kompeten/cukup/tidak kompeten) seperti pada gambar 1 berikut ini : 


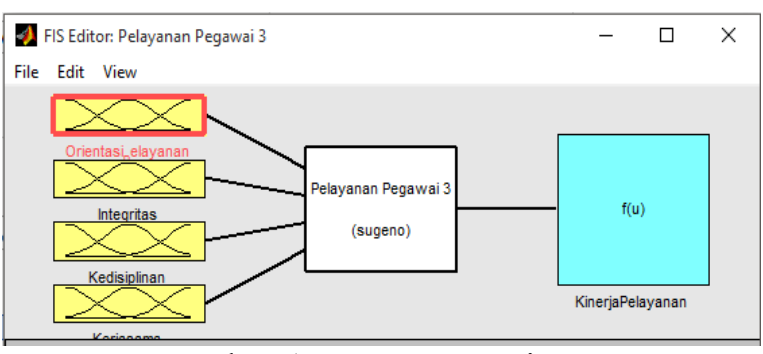

Gambar 1. Rancangan Sistem

Himpunan fuzzy yang dibuat untuk tiaptiap variabel input dan output adalah sebagai berikut: (1) Variabel Input, (a) Orientasi Pelayanan, himpunan universal untuk orientasi pelayanan adalah nilai minimum 0 dan nilai maksimum 100 maka himpunan universal untuk Orientasi Pelayanan yaitu $\mathrm{U} 1=\left[\begin{array}{ll}0 & 100\end{array}\right]$; (b)Integritas, himpunan universal untuk integritas adalah nilai minimum 0 dan nilai maksimum 100 maka himpunan universal untuk Integritas yaitu U1 = [0 100]; (c) Kedisiplinan, himpunan universal untuk kedisiplinan adalah nilai minimum 0 dan nilai maksimum 100 maka himpunan universal untuk Kedisiplinan yaitu U1 $=\left[\begin{array}{ll}0 & 100\end{array}\right]$; (d) Kerjasama, himpunan universal untuk kerjasama adalah nilai minimum 0 dan nilai maksimum 100 maka himpunan universal untuk Kerjasama yaitu U1 = [0 100]; (2) Variabel output , himpunan universal untuk variabel output adalah nilai 0 sampai 80 maka dinyatakan Kompeten, nilai 0 sampai 70 dinyatakan Cukup Kompeten dan $<50$ Maka dinyatakan Tidak Kompeten universal untuk Output yaitu Upenilaian $=[0$ 100]. (a) Himpunan Fuzzy, himpunan fuzzy dari masing-masing variabel input dan output dapat dilihat pada tabel 1 dibawah.

Tabel 1 Himpunan fuzzy

\begin{tabular}{|c|c|c|}
\hline Fungsi & Nama Variabel & Himpunan Fuzzy \\
\hline \multirow{11}{*}{ Input } & \multirow{3}{*}{$\begin{array}{l}\text { Orientasi } \\
\text { Pelayanan }\end{array}$} & Tidak Baik \\
\hline & & Baik \\
\hline & & Sangat Baik \\
\hline & \multirow{3}{*}{ Integritas } & Tidak Baik \\
\hline & & Baik \\
\hline & & Sangat Baik \\
\hline & \multirow{3}{*}{ Kedisiplinan } & Tidak Disiplin \\
\hline & & Disiplin \\
\hline & & Sangat Disiplin \\
\hline & \multirow[b]{2}{*}{ Kerjasama } & Tidak Bisa \\
\hline & & Bisa \\
\hline \multirow{3}{*}{ Output } & \multirow{3}{*}{ Penilaian } & Kompeten \\
\hline & & Cukup \\
\hline & & Tidak Kompeten \\
\hline
\end{tabular}

Semesta Pembicaraan, semesta pembicaraan dari masing-masing himpunan variabel input dan output dapat dilihat pada tabel 2 dibawah.

Tabel 2 Semesta Pembicaraan

\begin{tabular}{|c|c|c|c|}
\hline Fungsi & Variabel & \begin{tabular}{|l|} 
Semesta \\
Pembicaraan
\end{tabular} & Keterangan \\
\hline \multirow[t]{4}{*}{ Variabel } & $\begin{array}{l}\text { Orientasi } \\
\text { Pelayanan }\end{array}$ & {$[0-100]$} & $\begin{array}{l}\text { Nilai Orientasi } \\
\text { Pelayanan }\end{array}$ \\
\hline & Integritas & {$[0-100]$} & Nilai Integritas \\
\hline & Kedisiplinan & {$[0-100]$} & Nilai \\
\hline & Kerjasama & {$[0-100]$} & Nilai Kerjasama \\
\hline \multirow[t]{3}{*}{ Output } & Kompeten & {$[0-80]$} & $\begin{array}{l}\text { Pegawai } \\
\text { Berkompeten }\end{array}$ \\
\hline & Cukup & {$[0-70]$} & $\begin{array}{l}\text { Pegawai Cukup } \\
\text { Kompeten }\end{array}$ \\
\hline & \begin{tabular}{|l|} 
Tidak \\
Kompeten
\end{tabular} & {$[0-50]$} & $\begin{array}{l}\text { Pegawai Tidak } \\
\text { Kompeten }\end{array}$ \\
\hline
\end{tabular}

\section{Fungsi Keanggotaan}

Fungsi keanggotaan variabel input, fungsi keanggotaan variabel input Orientasi Pelayanan dibentuk menjadi tiga himpunan fuzzy yang menggunakan bentuk kurva segitiga untuk himpunan (tidak baik, baik, sangat baik) seperti gambar 2 dibawah ini.

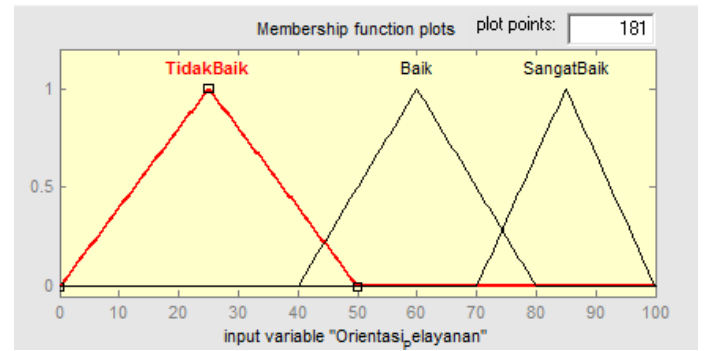

Gambar 2 Fungsi keanggotaan variabel Orientasi Pelayanan

Fungsi keanggotaan variabel output Pemilihan, himpunan fuzzy output pada penelitian ini dibagi menjadi 3 yaitu Kompeten dengan nilai tegasnya adalah 80, Cukup nilai tegasnya adalah 70 dan Tidak Kompeten dengan nilai tegasnya adalah 50 seperti gambar 3 dibawah ini.

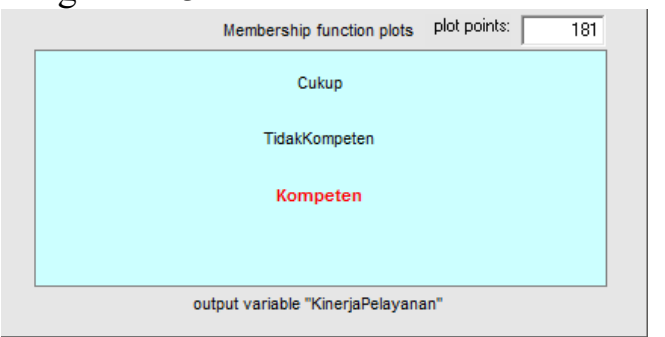

Gambar 3 Fungsi keanggotaan variabel output penilaian

Penyelesaian Masalah Menggunakan Metode Sugeno

Penyelesaian masalah untuk menentukan penilaian kinerja pegawai di Kantor Lurah Kibing Kecamatan BATAM KOTABatam dengan logika 
fuzzy menggunakan metode Sugeno, adalah sebagai berikut:

Menentukan variabel yang terkait dalam proses yang akan ditentukan dan fungsi fuzzifikasi yang sesuai dari sampel untuk menentukan penilaian kinerja pegawai yang kompeten atau tidak kompeten, dan ada 3 sampel yang akan di uji pada penelitian ini, ada 4 variabel yang akan dimodelkan yaitu:

Tabel 3 Data Penilaian kinerja pegawai dari Kecamatan Batam Kota

\begin{tabular}{|c|c|c|c|c|}
\hline \multirow{2}{*}{$\begin{array}{c}\text { Data } \\
\text { Pegawai }\end{array}$} & \multicolumn{4}{|c|}{ Variabel } \\
\cline { 2 - 5 } & $\begin{array}{c}\text { Orientasi } \\
\text { Pelayanan }\end{array}$ & Integritas & Kedisiplinan & $\begin{array}{c}\text { Kerja } \\
\text { sama }\end{array}$ \\
\hline $\begin{array}{c}\text { Wiwied } \\
\text { Indartono }\end{array}$ & 80 & 80 & 85 & 79 \\
\hline $\begin{array}{c}\text { Arnold } \\
\text { Mamopar }\end{array}$ & 78 & 78 & 70 & 70 \\
\hline $\begin{array}{c}\text { Liat Butar- } \\
\text { butar }\end{array}$ & 65 & 60 & 70 & 65 \\
\hline
\end{tabular}

Hasil defuzzifikasi hasil mengitung manual pada pegawai 2 adalah 80 yang berarti Penilaiannya adalah Kompeten.

Selanjutnya Perbandingan dengan menggunakan Matlab, dengan memasukan nilai input Pegawai 2 pada matlab. Seperti gambar 4 berikut:

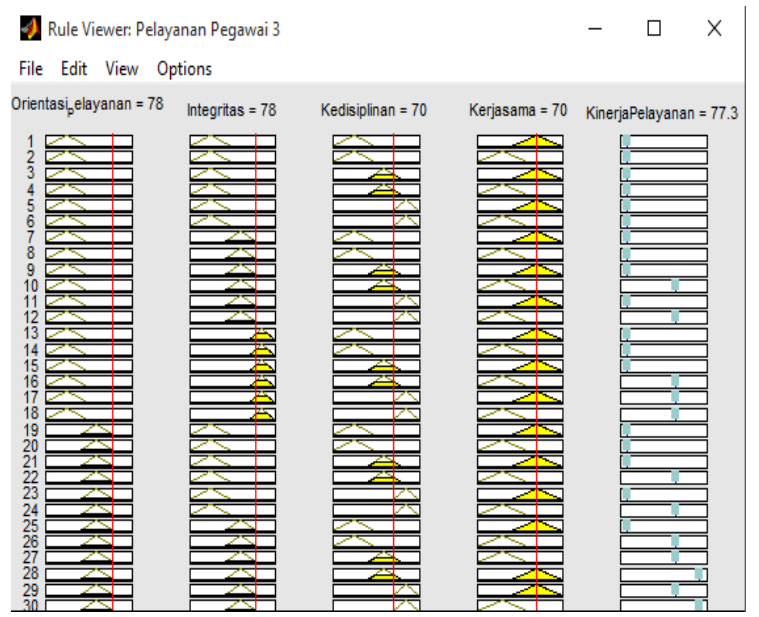

Gambar 4 Defuzzifikasi Matlab pegawai 2

\section{Hasil Penelitian}

Pembuatan model fuzzy untuk penilaian kinerja pegawai belum dikatakan baik sehingga perlu dilakukan pengujian terhadap pegawai sebanyak 3 sampel tentang keakuratan dan error dari pengujian. Pengujian ini menggunakan tingkat keakuratan.

Tabel 4 Review Pengujian

\begin{tabular}{|l|c|c|c|}
\hline \multicolumn{1}{|c|}{ Pegawai } & $\begin{array}{c}\text { Hasil } \\
\text { Defuzzifikasi }\end{array}$ & $\begin{array}{c}\text { Hasil } \\
\text { Matlab }\end{array}$ & Keterangan \\
\hline $\begin{array}{l}\text { Wiwied } \\
\text { Indartono }\end{array}$ & 80 & 80 & Benar \\
\hline $\begin{array}{l}\text { Arnold } \\
\text { Mamopar }\end{array}$ & 80 & 77,3 & Benar \\
\hline Liat Butar-butar & 80 & 80 & Benar \\
\hline
\end{tabular}

\section{PENUTUP}

\section{Kesimpulan}

Berdasarkan dari penjelasan pada bab sebelumnya dengan mengimplementasikan langkah-langkah untuk mengevaluasi kinerja pelayanan pegawai didalam penelitian dapat disimpulkan:

1. Menerapkan fungsi keanggotaan: (a) Membentuk himpunan universal untuk input dan output; (b) Memasukkan fungsi keanggotaan pada himpunan-himpunan fuzzy yang ada variabel input; (c) Menggunakan kurva yang menunjukkan pemetaan titik-titik input data ke dalam nilai keanggotaannya yaitu trimf; (d) Melakukan proses pembentukan aturan fuzzy (rule) yang berjumlah 54 dengan penalaran logika; (e) Mendefinisikan himpunan fuzzy untuk setiap variabel input dan output; (f) Mencari derajat keanggotaan nilai tiap variabel dalam setiap himpunan dengan menggunakan persamaan yang ada; (g) Melakukan inferensi dari aturan fuzzy;

2. Tingkat keakuratan penentuan evaluasi kinerja pegawai menggunakan logika fuzzy adalah sebesar $100 \%$ dengan error $0 \%$.

\section{REFERENSI}

Alamsyah dan Muna. (2016). Jurnal Metode Fuzzy Inference System untuk Penilaian Kinerj Pegawai Perpustakaan dan Pustakawan. Scientific Journal of Informatics. Vol.3 No.1.2407-7658.

Budiharto, Widodo dan Derwin Suhartono. (2014). Artificial Intelligence: Konsep dan Penerapannya. Andi. Yogyakarta. 
Kasmir. (2016). Manajemen Sumber Daya Manusia (Teori dan Praktik). PT RajaGrafindo Persada. Jakarta.

Kusumadewi, Sri dan Hari Purnomo. (2010). Aplikasi Logika Fuzzy untuk Pendukung Keputusan: Edisi 2. Graha Ilmu. Yogyakarta.

Mustika dan Sutrisno. (2016). Jurnal Model Evaluasi Kinerja Karyawan Dengan Menggunakan

Metode Fuzzy Sugeno Pada Resto ABTL. Jurnal String. Vol.1 No.1. 2527-9661.

Muthohar dan Rahayu. (2015). Jurnal Metode Fuzzy Mamdani untuk Evaluasi Kinerja Pelayanan Perawat. Jurnal Penelitian. Volume 1 No.1. 8-17.

Naba Agus. (2009). Buku Belajar Cepat Fuzzy Logic Menggunakan Matlab. Penerbit Andi. Yogyakarta.

Purwanti dan Widodo. (2014). Model Penduga Kinerja Pegawai Berdasarkan Pendekatan FIS Mamdani Studi Kasus Badan Kependudukan dan Keluarga Berencana Nasional. Jurnal Faktor Exacta. 7(3): 271- 281. 1979-276x.

Rofiq. (2013). Jurnal Perancangan Manajemen Bandwith Internet Menggunakan Metode Fuzzy Sugeno. Jurnal Ilmiah Teknologi dan Informasi ASIA. Vol.7 No.1

Sutojo, Mulyanto dan Suhartono. (2011). Kecerdasan Buatan. Penerbit Andi. Yogyakarta. Yani. (2012). Manajemen Sumber Daya Manusia. Mitra Wacana Media. Jakarta. 